\title{
AZ IMMATERIÁLIS JAVAKKAL KAPCSOLATOS KÖZZÉTÉTEL VIZSGÁLATA TARTALOMELEMZÉSSEL A LEGNAGYOBB HAZAI VÁLLALKOZÁSOKNÁL'
}

Kovács Zsuzsanna Ilona - Lippai-Makra Edit-

Kiss Gábor Dávid - Deák István ${ }^{2}$

\begin{abstract}
ABSZTRAKT
Kutatásunk a tartalomelemzés módszerére építve tárta fel a 2012-ben és 2017-ben is a legnagyobb harminc hazai vállalat körébe tartozó gazdálkodók immateriális tételekkel kapcsolatos beszámolási kultúráját. Az eredmények alapján a vizsgált két üzleti év között a pontértékek nagyon mérsékelt átlagos növekedést mutatnak, amely jelentősen kevesebb a szakirodalomban fellelt növekedési rátáknál. A vizsgált gazdálkodók a szellemi tulajdonról, cégértékről, illetve a mérlegben szereplő immateriális tételeikről, valamint a környezeti és egyéb tényezőkről kommunikáltak legintenzívebben. M-becslést alkalmazó robusztus regressziós számításaink alapján 2017-re az iparági különbségek, a tőzsdei jegyzés, illetve az árbevétel váltak meghatározóvá a beszámolók információtartalmának minősége szempontjából.
\end{abstract}

JEL-kód: $\mathrm{M}_{41}$

Kulcsszavak: immateriális javak, önkéntes közzététel, robusztus regresszió, tartalomelemzés

1 A kutatást az EFOP-3.6.2-16-2017-00007 azonosító számú, Az intelligens, fenntartható és inkluziv társadalom fejlesztésének aspektusai: társadalmi, technológiai, innovációs hálózatok a foglalkoztatásban és a digitális gazdaságban című projekt támogatta. A projekt az Európai Unió támogatásával, az Európai Szociális Alap és Magyarország költségvetése társfinanszírozásában valósul meg.

2 Kovács Zsuzsanna Ilona $\mathrm{PhD}$, adjunktus, Szegedi Tudományegyetem Gazdaságtudományi Kar, PNGKI, Szeged.E-mail: zsuzsanna.k@eco.u-szeged.hu.

Lippai-Makra Edit tanársegéd, Szegedi Tudományegyetem Gazdaságtudományi Kar, PNGKI, Szeged. E-mail: makra.edit@eco.u-szeged.hu.

Kiss Gábor Dávid PhD, docens, Szegedi Tudományegyetem Gazdaságtudományi Kar, PNGKI, Szeged. Email: kiss.gabor.david@eco.u-szeged.hu.

Deák István PhD, docens, Szegedi Tudományegyetem Gazdaságtudományi Kar, PNGKI, Szeged. E-mail: deak@eco.u-szeged.hu. 


\section{BEVEZETÉS}

A gazdálkodóktól az érdekeltek azt várják, hogy minden, a befektetési és hitelnyújtási döntéseiket támogató információval lássák el őket, az immateriális erőforrásokról szóló releváns információkat is ideértve. A pénzügyi beszámolási szabályozásokat azzal a céllal alkotják, hogy az érdekhordozókkal folytatott kommunikációt egységesítsék, megadják annak módját, illetve azt a minimális tartalmat, amellyel el kell látni a külső feleket. A minimális tartalmon felül azonban a cégek önkéntes alapon is hozhatnak - és hoznak is - nyilvánosságra adatokat. Erre az sarkallja őket, hogy az információ előállításának költségét várhatóan meghaladja a haszon, amelyet elérnek a segítségével. Shehata (2014) az önkéntes közzétételnek a gazdaságban betöltött szerepével kapcsolatos közgazdasági elméleteket foglalja össze: ügynökelmélet, jelzéselmélet, tőkeszükséglet, legitimációs elmélet. A beszámolóban kötelezően szerepeltetendő információkon felüli önkéntes adatközlést a szerző az ügynökprobléma egyfajta kezelési módjaként említi, mivel segít a tulajdonosok mint megbízók és a menedzserek mint ügynökök között fennálló információs aszimmetria csökkentésében.

Boda et al. (2019) szerint a fenntartható felzárkózásban a gazdaságszerkezet módosítása és az ipar fejlesztése mellett az iparon kívüli, tudástartalomra épülő ágazatok játszanak döntő szerepet. Petty et al. (2009) kifejtik: konszenzus alakult ki a szakmában arra vonatkozóan, hogy az intellektuális tőkét három nagy halmazra lehet bontani, humán tőkére, belső tőkére és külső tőkére. Sveiby a láthatatlan mérleghez hasonlóan szemlélteti az immateriális tőkét, amelyet az alábbi kategóriák szerint jelenít meg:

- humán struktúra: egyéni kompetenciák, képességek, képzettség, tapasztalat

- belső struktúra: szabadalmak, elméletek, modellek, informatikai rendszerek, vállalati kultúra

- külső struktúra: vevői és szállítói kapcsolatok, márkanevek, kereskedelmi nevek, hírnév, imidzs (Sveiby, 2001:64-66).

A jelenlegi pénzügyi beszámolási standardok elöírásai mellett igen szűk azon immateriális javak köre, amelyek megjelenhetnek a vállalatok mérlegeiben. Ez igaz mind a hazai számviteli szabályok, mind a nemzetközi standardok esetében is - bár eltérő okokból. Hazánkban a törvény szabályalapú megközelítést követ, megadja a megjeleníthető tételeket és elöírja tartalmukat. A nemzetközi pénzügyi beszámolási standardok (IFRS) elvi alapú megközelítéssel, definíciók és megjelenítési kritériumok alapján szűkítik a kört. Bármely szabályozást is tekintjük, kijelenthető, hogy a vállalkozások által hasznosított immateriális erőforrások köre jóval szélesebb annál, mint amit a pénzügyi kimutatásokban olvashatunk. Emiatt számos kritika éri a standardalkotókat, régóta fennálló vita folyik a szakemberek 
között: jobb megoldás lenne bővíteni a mérlegképes vagyonelemek körét, vagy éppen hiba lenne bizonytalan megtérüléssel rendelkezö eszközöket kimutatni? A pro érveket a teljesség elvével, illetve a relevanciával támaszthatjuk alá: a kimutatásokat hasznosító érdekhordozóknak teljes körü tájékozottságra van szükségük, minden olyan tényezőt ideértve, amely hatással lehet a döntéshozatalra. Ugyanakkor a megbízhatóság megköveteli, hogy a beszámolóban szereplő értékek „objektív" mérési technikákon alapuló, hibáktól és torzításoktól mentes adatok legyenek. Ennek eredményeként a legtöbb esetben a belső előállítású immateriális erőforrásoknál a tárgyév eredményének terhére történő elszámolást kell alkalmazni. A költségként való megjelenítéssel nem visznek be bizonytalan megtérüléssel múködő eszközöket a beszámolóba, viszont Lev (2003) is felhívja a figyelmet arra, hogy a látszólag konzervatív megközelítés, vagyis a költségként történő leírás és az eredmény alábecslése más periódusokban éppen az ellenkező hatást generálja, vagyis „agresszív” módon felduzzasztott eredményhez vezet a későbbiekben. Az EFRAG (European Financial Reporting Advisory Group) - amely az „európai véleményt” képviseli a standardalkotásban - nemrég kiadott egy átfogó tanulmányt e témában, amely azzal a gondolattal zárul, hogy paradox helyzethez érkeztünk az immateriális javak miatt: egyrészt egyfajta motorként funkcionálva erősítik a gazdaságunkat, segítik a hozzáadott érték termelését. Ugyanakkor a bizonytalanságuk, kisebb fokú stabilitásuk és a kockázatosságuk miatt sebezhetőséget is hoznak a rendszerbe (Zambon et al., 2020).

A mérlegből hiányzó tételek nagyságrendjét adja meg a Brand Finance (2018:2425) a 2017-es üzleti évre vonatkozóan: a világ összes tőzsdei vállalatához tartozó piaci érték 52 százaléka adódott az immateriális tételekből, ezen belül 7 százalék a goodwill, 5 százalék a beszámolóban megjelenő és 40 százalék a beszámolóban nem számszerüsített érték volt. Ez magyarországi megfigyelések szerint hazánkban sincsen másképp: Juhász (2016) széleskörü megkérdezésen alapuló elemzése alapján a hazai vállalatvezetők véleménye szerint a vállalatok értékének fele nem jelenik meg a könyv szerinti értékükben. A döntéshozatalhoz azonban szükséges a nem mérlegképes elemek ismerete is, ugyanis csak a teljes vagyon értelmezésében végezhetők el azok a hozamszámítások, amelyek alapján megállapítható, hol és miként kell beavatkozni a müködésbe (Laáb, 2010). Saxné Andor (2014) empirikus kutatást végzett az immateriális javakkal kapcsolatos számviteli szabályozások alkalmazásáról a hazai vállalatok körében. Vizsgálata érintette a mérlegben való megjelenítés, az év végi értékelés és a szöveges mellékletekben történő kötelező és önkéntes információközlés témaköreit. Eredményei szerint a hazai vállalkozások a müködésüket szolgáló immateriális erőforrások nagy részét nem mutatták ki a beszámolóban a szabályozásokból következően.

Némileg nehezíti a tájékozódást, hogy a szakirodalomban többféle módon írják körül ezt a többletet: szellemi tőke, humán tőke, tudástőke, intellektuális tőke 
megnevezések is megjelennek. Az itt felsorolt elemeket gyakran eltérő tartalommal használják, így jelen tanulmányban csak akkor alkalmazzuk az adott fogalmat, ha más szerzőhöz kötődő gondolatokat idézünk. „Immateriális javakként” említjük azokat az eszközöket, amelyek megfelelnek a számviteli vagyonba illesztés kritériumainak, míg „immateriális erőforrások, illetve tételek” alatt olyan tényezők széles körét értjük, amelyek nem anyagi természetűek, a tágabban értelmezett gazdálkodói vagyon részét képezik, és nem feltétlenül mérlegképesek. A „tudásjavak” kifejezést akkor használjuk, amikor a megfoghatatlan erőforrások olyan tágabb körére utalunk, amelyek valamilyen módon a tudásra épülnek, a vállalkozások számára fontosak, de nem feltétlenül teljesítik a mérlegképességi kritériumokat.

Az immateriális tételek különleges szerepe Orhangazi (2019) szerint abban áll: anélkül teszik lehetővé a profit növelését, hogy további fizikai tőke bevonása lenne szükséges. A szerző ezt azzal magyarázza, hogy a szabadalmak, a márkák, a kereskedelmi védjegyek és egyéb szellemi tulajdonhoz füződő jogok birtoklása erős pozíciót biztosít a vállalatok számára, monopóliumokat hozhat létre, és lehetővé teheti a termékek optimális árazását - magasan a gyártási költségek felett. Ez utóbbi előnyök birtoklása nagyon értékessé teheti egyes vállalatok részvényeit a befektetők számára, tehát az immateriális erőforrásokról szóló, a gazdálkodók által közölt információ hasznos az érdekhordozók számára. Gambetti et al. (2017) kiemelik, hogy az erős piaci pozíció nem csupán hatalommal, de felelősséggel is jár, hangsúlyozva az immateriális erőforrások etikus menedzsmentjének fontosságát. A felelős vállalatoknak eszerint folyamatosan párbeszédet kell folytatniuk az érdekhordozókkal. A kommunikáció egy olyan szövetséget hivatott fenntartani, amelyben a vállalat és az érdekeltek közös értékek és célok mentén együtt építik és birtokolják az immateriális vagyont, amelynek legfontosabb elemei a szervezet identitása, márkája és hírneve. A fent említett párbeszéd, illetve tájékoztatás természetesen sok csatornán megtörténhet, akár a beszámoló szöveges részeiben is, vagyis a számszaki részek kiegészítő mellékleteiben, illetve a vezetőségi jelentésekben.

Jelen tanulmányban a szakirodalomban fellelt, hasonló kutatások eredményeinek összefoglalása után bemutatjuk azon empirikus elemzésünket, amelyben egy nemzetközi módszertan alapján értékeljük a legnagyobb magyar vállalkozások immateriális tételekkel kapcsolatos közzétételi gyakorlatát. Kutatásunk korábbi és jelenlegi szakasza a 2012-es és 2017-es üzleti éveket öleli fel, lehetőséget adva az időbeli változások megfigyelésére is. 


\section{KORÁBBI KUTATÁSOK EREDMÉNYEI}

Amennyiben a vállalkozások az önkéntes közzététel mellett vannak, arról is dönteniük kell, hogy ezt milyen kommunikációs csatorna segítségével teszik meg. A pénzügyi beszámoló szöveges mellékleteiben, esetleg a vezetőségi jelentésekben vagy teljesen különálló dokumentumokban is publikálhatnak információkat. A KPMG felmérése szerint (KPMG International, 2020:12) a legnagyobb európai vállalatok 77 százaléka publikál társadalmi felelősségvállalásról szóló jelentést, azonban a kontinens nem egységes. Kelet-Európában az arány ugyan kisebb, viszont jelentős növekedés történt az elmúlt három évben, míg Nyugat-Európában a növekedés lelassult. A vállalatok által publikált önkéntes jelentések tartalmazhatnak jelentős mennyiségü információt az immateriális erőforrásokról (például az emberi erőforrások menedzseléséről, illetve a vevői és szállítói kapcsolatok minőségéről), azonban a pénzügyi beszámolóval ellentétben nem eredményeznek az érdekhordozók számára minden üzleti évre rendelkezésre álló, összehasonlítható információkat. A jövőben megvalósulhat, hogy a gazdálkodók egy jelentésben kezelik a pénzügyi adatokat a nem pénzügyi tényezőkkel, az integrált jelentéskészítés elterjedésére azonban még várnunk kell. Amíg ez általánossá nem válik, addig az érdekhordozók számára az egyetlen rendelkezésre álló, rendszeresen publikált, összehasonlítható alapokon készülő jelentéscsomag a pénzügyi beszámoló marad.

A szabályozásoktól függetlenül tagadhatatlan tény, hogy az immateriális erőforrások nagyon értékesek a vállalkozások számára, több okból kifolyólag is. Castilla-Polo-Ruiz-Rodríguez (2017) szerint értéküket az adja, hogy egymást kiegészítik, pótolhatatlanok és nem sokszorosíthatók. Mindebből az is következik, hogy a hagyományos számviteli és kontrollingeszközökkel történő megközelítések itt nem feltétlenül működnek. A gazdálkodók ennek megfelelően találtak arra módot, hogy a beszámolók szöveges részében vagy egyéb jelentések formájában tájékoztassák az érdekelteket e jelenségekről. Az utóbbi évtizedben egyre gyakrabban tesznek közzé olyan dokumentumokat, amelyek a gazdálkodók társadalomban betöltött szerepéről, a vállalatok irányításának elveiről vagy a fenntartható működésről szólnak (ún. ESG-jelentések). A kutatások többsége mégsem ezeket a csatornákat, hanem a pénzügyi beszámolókat elemzi, mivel ezek egységes alapokon készülnek és hozzáférhetők, valamint jó közelítést adnak arról, hogy mennyire közlékeny az adott vállalkozás az immateriális erőforrásaival kapcsolatban (OECD, 2012).

Albu et al. (2017) szerint a kelet-közép-európai régió országaiban eleve a pénzügyi beszámolási infrastruktúra jelentős fejlődésére volt szükség, így fontos az egyes országok beszámolási kultúrájának vizsgálata. A szerzők kifejtik továbbá, hogy a kutatási kérdéstől függően és a felhasznált adatok típusa alapján az egy országot 
vizsgáló tanulmányokban az eredmények szolgálhatnak „egyedi” esetleírásként vagy példaként, amellyel a hasonló intézményi háttérrel rendelkező országokat kívánják bemutatni.

Az immateriális javakkal kapcsolatos közzétételt vizsgálta Novák (2018) az IAS 38 szabályozásaival összefüggésben: cseh tőzsdei vállalkozásokból álló mintát elemezve arra a következtetésre jutott, hogy a közzététel szintje alacsony - leginkább a gyártó vállalatok feleltek meg az elöírásoknak. Oliveira et al. (2006) európai környezetben végzett tartalomelemzésre épülő felmérést: a portugál tőzsdén jegyzett 56 vállalkozás esetében vizsgálták a közzétételt a 2003-as üzleti évre vonatkozóan. Az intellektuális tőkének a szakirodalom által definiált három csoportja közül a humán tőkével kapcsolatos információkból közöltek a legkevesebbet a strukturális és kapcsolati tőke kategóriákhoz viszonyítva. $L i$ et al. (2008) ugyanezt a három kategóriát állították az elemzés középpontjába, amikor a vállalatirányítási struktúra és az intellektuális tőkével kapcsolatos közzététel közötti összefüggést vizsgálták. A londoni tőzsdén jegyzett vállalkozásokból vettek hét különböző iparágat felölelő, 100 elemű mintát. A gazdálkodók 2004 márciusa és 2005 februárja között közzétett éves jelentéseit kifinomult tartalomelemzésnek vetették alá, amely a közzététel megléte, illetve elmaradása mellett annak intenzitását és a fókuszban szereplő tételek megtalálását is lehetővé tette. A kutatók összefüggést találtak az intellektuális tőkével kapcsolatos közzététel és olyan független változók között, mint az igazgatótanács összetétele, a tulajdonosi szerkezet, az auditbizottság mérete, üléseinek gyakorisága.

Más szerzők is átvették a Li et al. (2008) által kialakított indexet (vagyis azon tételek listáját, amelyeket az éves jelentésekben kerestek). Boujelbene-Affes (2013) francia jegyzett gazdálkodók esetében mutattak ki összefüggést az intellektuális tőkéről szóló közzététel mint független változó és a tőkeköltség mint függő változó esetében. A szerzők megkülönböztették a high-tech cégeket a hagyományos iparágak szereplőitől, illetve megállapították, hogy szignifikáns negatív kapcsolat van a tőkeköltség és az intellektuális tőke két komponensének (humán és strukturális tőke) közzététele között. Bogdan et al. (2011) szintén a Li-féle módszert használták, és 19 bukaresti tőzsdén jegyzett társaságot vizsgáltak öt éven keresztül (2005-2009). A szerzők szerint, bár az átlagos közzétételi pontok a vizsgált időszak alatt növekedtek, de alacsonynak mondható a mintában szereplő cégek közzétételi aktivitása. Petty et al. (2009) szerint a széleskörű jelentéskészítés legnagyobb akadálya a közzétételi módszerek közötti konzisztencia hiánya, illetve az, hogy nehéz az egyes kategóriákhoz megfelelő számszerüsített értéket hozzárendelni.

Ho et al. (2012) a hongkongi tőzsde esetében elemezte a gazdálkodók legelső nyilvános tőzsdei kibocsátása (IPO) és az intellektuálistőke-elemek közzététele közötti összefüggést. A 2008-2010 közötti időszakra kiválasztott minta alapján 
megállapították, hogy a közzététel és a befektetői bizalom között szignifikáns pozitív kapcsolat van. Az empirikus elemzések tehát alátámasztják, hogy az érdekhordozókkal folytatott kommunikációból a gazdálkodóknak előnyei származnak, mivel a befektetők értékelik a részükre szolgáltatott többletinformációkat.

Mivel a későbbiekben bemutatott saját elemzésünk egy nemzetközi szakirodalomban fellelt kutatásra épül, így e szerző eredményeit részletesebben bemutatjuk. Ragini (2012) öt éven keresztül (2001-2005) elemezte indiai, egyesült államokbeli és japán cégek éves beszámolóit olyan céllal, hogy azonosítsa az ezekben megjelenő immateriális tételeket. A mintába a legnagyobb egyesült államokbeli (100), indiai (100) és japán (60) cégek kerültek, azonban a tényleges számítások ennél kevesebb beszámoló alapján készültek, mivel nem minden esetben sikerült hozzáférni a kimutatásokhoz. Ragini 18o immateriális tételt azonosított, és megszámolta, hogy az adott beszámolóban ezek közül hányról található információ.

A tételeket a következő témák köré csoportosította:

a) kutatás-fejlesztés (20 tétel),

b) stratégia és verseny (30 tétel),

c) piac és fogyasztó (36 tétel),

d) humán erőforrás (26 tétel),

e) szellemi tulajdonnal kapcsolatos jogok, cégérték és más immateriális javak (25 tétel),

f) vállalati és tulajdonosi információ (18 tétel),

g) környezeti és egyéb immateriális tényezők ( 25 tétel).

Az eredmények alapján arra jutott, hogy öt év alatt mindhárom vizsgált országra vonatkozóan folyamatosan nőtt a pontok átlagos értéke. 2001 kivételével mindig az egyesült államokbeli cégek átlaga volt a legmagasabb. Másodikként az indiai cégek következnek, kivéve a 2005-ös évet, amikor a japán átlag lett a második legmagasabb. A közzététel jellegét tekintve az indiai cégek a kutatás-fejlesztésről és a humán erőforrásról; az amerikai vállalatok a stratégiáról és versenyről, a piacról és fogyasztókról, illetve a szellemi tulajdonról publikáltak kiemelkedően sok adatot; a japán cégek pedig a vállalati és tulajdonosi információkra és a környezeti tényezőkre fókuszáltak leginkább. Az adatok elemzése során a szerző megkísérli a vállalkozások által elért pontokat összefüggésbe hozni olyan tényezőkkel, mint a vállalat mérete, nyereségessége, tőkeszerkezete, könyv szerinti érték- és piaci értékhányadosa, illetve az iparág. Az eredmények alapján kiemeli, hogy az indiai cégek esetében a vállalat mérete és nyereségessége, az egyesült államokbeli vállalkozásoknál az iparág, Japán esetében pedig a vállalati méret van összefüggésben az elért pontokkal (Ragini, 2012). 


\subsection{Elméleti modell}

A szakirodalom alapján látható, hogy az immateriális tételekről szóló közzététel (S) alakulása az alábbi jellemzőktől függhet: a vállalat mérete (nettó árbevétel), illetve jövedelmi helyzete (adózás előtti eredmény) (EK), az eszközállomány öszszetétele $(E)$, a tözsdei jegyzés $\left(d \_t\right)$ és az iparág $\left(d \_I\right)$, amelyben tevékenykedik, így az elméleti modellt az alábbi (1) módon építettük fel:

lnS $=$ konst. $+\beta_{1} \ln E K+\beta_{2: k} \ln E+\beta_{k+1} d_{t}+\beta_{k+2: n} d_{-} I+\varepsilon$

ahol $\varepsilon$ a nem autokorrelált és normális eloszlású hibatag.

A vállalat méretére vonatkozóan a nettó árbevétel logaritmizált értékét vettük alapul $\left(E K_{N A B}\right)$, a jövedelmi helyzetet pedig leírhatjuk az adózás előtti eredmény $\left(E K_{A E E}\right)$ logaritmizált értékével. Az eszközállomány összetételét az immateriális javak $\left(E_{I J}\right)$ logaritmizált, illetve a mérlegföösszeggel arányosított értékével $\left(E_{\frac{I J}{M F O}}\right)$ vizsgáltuk. ${ }^{3} \mathrm{Az}$ iparági besorolás során statisztikai szempontok miatt megkülönböztettük a gépiparban, illetve acélgyártásban $\left(d_{-} I_{g}\right)$ és az elektronikai, illetve híradástechnikai cikkek gyártásában $\left(d_{-} I_{e}\right)$ tevékenykedő vállalatokat. A hibataggal kapcsolatban megfogalmazott elvárások fényében elvégeztük az egyes alternatív modellek összehasonlítását, amelynek eredményeként az alábbi (2) elméleti modellel számoltunk:

$\ln S=$ konst. $+\beta_{1} \ln E K_{N A B}+\beta_{2} \ln E_{I J}+\beta_{3} \ln E_{\frac{I J}{M F O}}+\beta_{4} d_{-} t+\beta_{5} d_{-} I_{g}+\beta_{6} d_{-} I_{e}+\varepsilon$

Az egyes koefficiensekkel kapcsolatban az alábbi intuitív várakozásokat fogalmazhatjuk meg: a magasabb árbevétel (Ragini, 2012 nyomán), illetve a jelentősebb immateriális eszközállomány (Lippai-Makra et al., 2019 nyomán) motiválja a cégeket a részletesebb jelentéstételre, miután a nem pénzügyi tételeknek a vállalat értékében komolyabb jelentőségük van.

3 A nettó árbevétel, adózás előtti eredmény, mérlegföösszeg, illetve az immateriális javak értékeit a beszámolók adatai alapján, forintban határoztuk meg. 


\section{EMPIRIKUS ELEMZÉS}

A mintaválasztás egy korábbi kutatásunk eredményeire épült (Kovács, 2015): e szakaszban a Figyelő által készített TOP 200 listán (Figyelö, 2013) szereplő vállalatokat vettük alapul, ahol a 2012. évi nettó árbevétel alapján a 30 legnagyobb vállalat egyedi beszámolójának vizsgálatát tűztük ki célként a Ragini-féle módszer alapján (ekkor az egyedi beszámolók egységesen a számviteli törvény szabályozásainak megfelelően készültek, és 29 esetben voltak elérhetők). A korábbi elemzés elvégzése után a következő megállapításokat tettük:

1. A magyar mintában szereplő vállalatok immateriális tételekkel kapcsolatos beszámolási gyakorlatát a szöveges mellékletekben kötelezöen elöírt tartalmak határozták meg.

2. Az önkéntes alapon közölt és nyilvánosságra hozott adatok inkább azon tőzsdei cégek esetében voltak jellemzők, amelyek üzleti jelentést is csatoltak a beszámolókhoz.

Jelen kutatási szakaszban azon cégek beszámolóit elemeztük, amelyek a 2012-es mintában is szerepeltek, és 2017-ben még mindig tagjai a legnagyobb 30 árbevétellel rendelkező cégek csoportjának (Figyelö, 2018), tehát stabilan tartják a helyüket a legnagyobb gazdálkodók között. A 2017-es év kiválasztásának kritériuma az volt, hogy e kutatási szakasz megkezdésekor ez volt a legfrissebb rendelkezésre álló egyedibeszámoló-adatsor (látható a fent hivatkozott, hasonló módszert alkalmazó kutatások esetében, hogy a vizsgált időszak és az eredmények publikálása között általában több év telik el). A mintavételi eljárás tehát szakértői mintavétel, hasonlóan a 2. fejezetben említett, adott országok beszámolási kultúráját elemző vizsgálatokhoz, ahol egy adott paraméter alapján (például tőzsdei cégek, legnagyobb árbevétellel rendelkező cégek) történt az alanyok kiválasztása. A 2017-es évre vonatkozóan a tőzsdei cégek által elkészített, egyedi beszámolók már az IFRS szerint készültek a számviteli törvény 9/A. $\$$ alapján. Minden gazdálkodó esetében megvizsgáltuk az üzleti jelentés online elérhetőségét. A három tőzsdei vállalkozás mellett - ahol ez a szabályozások miatt kötelező - egy további gazdálkodó publikált olyan beszámolót, amely az üzleti jelenést is tartalmazta interneten elérhető formában.

Tartalomelemzésre ismét a Ragini-féle módszert használtuk, így lehetővé vált a mintában szereplő 17 cég pontjainak összehasonlítása mind egymással, mind saját korábbi pontszámukkal.

A vállalatok által elért pontszámokat a beszámolóban fellelt immateriális tételek száma adta, amelyet százalékos formában is kiszámítottunk a következőképpen:

pontszám $=\frac{\text { az adott beszámolóban megjelenő immateriális tételek száma }}{\text { a maximálisan megjeleníthető tételek száma }(180)} \times 100$ 
A továbbiakban a beszámolókhoz rendelt pontszámok alatt a fenti módszerrel kiszámított értékeket értjük, amely tehát minden esetben o és 100 közötti értéket vesz fel. Az általunk választott eszköz, a tartalomelemzés az immateriális tételekkel kapcsolatos közzététel és beszámolási kultúra vizsgálatára Castilla-PoloRuiz-Rodríguez (2017) alapján széles körben alkalmazott. A szerzők megemlítik továbbá a kivitelezés két fő formáját: a számítógépes és a manuális kódolást. Előbbi előnye az objektivitás, azonban Bellora-Guenther (2013) a kézi kódolás mellett érvel, mivel az olvasás és a jelentések tartalmának emberi értelmezése elengedhetetlen ahhoz, hogy a mögöttes tartalmakat figyelembe tudjuk venni. Jelenlegi kutatásunkat mindezek alapján a beszámolók olvasásával és „kézi” pontozásával folytattuk le a 2012-es és 2017-es beszámolók összevetésével.

Ragini eredményei alapján az indiai vállalatok beszámolóinak átlagos pontszáma 2001 és 2005 között átlagosan 7, az USA-ból származó cégeké 9, a japán vállalatoké pedig 12 százalékkal növekedett (1. táblázat). Amennyiben ez a növekedési ráta fennmaradt a vizsgálat utáni években, akkor a pontszámok azóta természetesen jelentősen magasabbak lehetnek.

1. táblázat

Ragini eredményei

\begin{tabular}{|c|c|c|c|}
\hline Ország & 2001 & 2005 & $\begin{array}{c}\text { Éves átlagos } \\
\text { növekedés }\end{array}$ \\
\hline India & 16,38 & 21,47 & $7,0 \%$ \\
\hline USA & 16,01 & 22,74 & $9,3 \%$ \\
\hline Japán & 14,05 & 22,38 & $12,7 \%$ \\
\hline
\end{tabular}

Forrás: Ragini (2012:58) adatai

Megjegyzés: *az éves átlagos növekedés saját számítás

A 17 cégből álló magyar minta átlaga 2012-re vonatkozóan 25,3, 2017-re 28,9 volt (2. táblázat). Mindkét vizsgált évre igaz, hogy a magas szórás miatt a mediánt érdemes figyelembe venni, ami 19, illetve 22. A hazai vállalatok pontszámainak egyszerű számtani átlaga 2012 és 2017 között átlagosan évente mindössze 2,7 százalékkal nőtt. 


\section{2. táblázat}

A magyar minta statisztikai jellemzői

\begin{tabular}{lcc}
\hline Jellemző/Időszak & $\mathbf{2 0 1 2}$ & $\mathbf{2 0 1 7}$ \\
\hline Átlag & 25,3 & 28,9 \\
Szórás & 15,1 & 19 \\
Medián & 19 & 22 \\
Minimum & 11 & 14 \\
Maximum & 59 & 69 \\
\hline
\end{tabular}

Forrás: saját számítások

A legmagasabb értékek 2017-ben is azon vállalatok esetében mutatkoznak, amelyek tőzsdei vállalkozásként üzleti jelentést is publikáltak - az átlag esetükben 65,74. Ezekröl elmondható, hogy jóval a minta átlaga feletti mértékben közöltek információkat az immateriális erőforrásaikról (1. ábra). A tapasztalat ismét azt mutatja, hogy az önkéntes alapon közölt, a minimumkövetelményeket lényegesen meghaladó információk egyrészt a tőzsdei cégek esetében jellemzők, amelyek IFRS-beszámolót készítettek, illetve publikussá tették az üzleti jelentésüket, valamint 2017-re vonatkozóan kiemelhető az az egy vállalat, amely nem tőzsdén jegyzett gazdálkodó, de ettől függetlenül online nyilvánossá tette az üzleti jelentését.

\section{1. ábra}

\section{Az egyes gazdálkodók beszámolóihoz rendelt pontszámok}

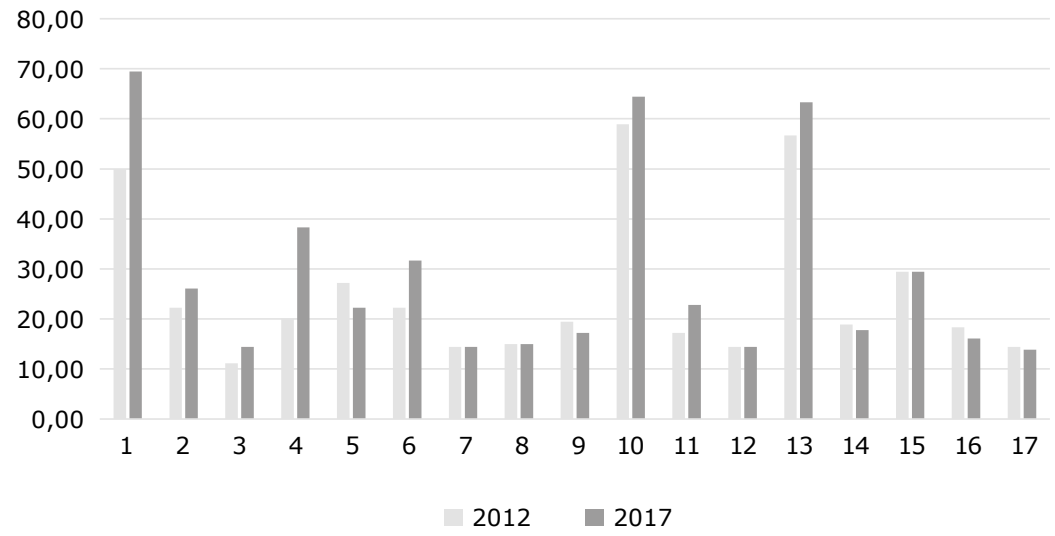

Forrás: saját szerkesztés

Megjegyzés: tőzsdei cég: 1, 10, 13; publikált online üzleti jelentést 2017-re: 4. 
A minimumértékek hasonlóak a két vizsgált évben, és minden esetben a számviteli törvény elöírásait alkalmazó, nem nyilvános társaságok beszámolói esetében fordulnak elö. Nullához közelítő értékek nincsenek, mivel a kötelező előírások miatt van az elért pontoknak egy olyan minimális értéke, amit elvileg minden vállalatnak el kell érnie, ha a törvénynek megfelelő éves beszámolót készít. Egységes konkrét minimumértéket nehéz meghatározni, mivel külön szabályok vonatkoznak például a tőzsdei vállalkozásokra, illetve az üzleti jelentés online hozzáférhetösége nem biztosított minden esetben. Kutatásunk korábbi szakaszában minimumértéknek - az üzleti jelentés tartalmát ide nem értve - 14,44-et határoztunk meg (lásd bővebben Kovács, 2015:235-236). Van tehát a tételeknek egy olyan halmaza, amely a közölt információk „gerincét” adják, és nagy gyakorisággal fordulnak elö. Ha a mintából kiemeljük a 2017-re online üzleti jelentést is publikáló négy vállalkozást, akkor ezek átlaga 19,66-ot mutat, ami nem sokkal haladja meg a számviteli törvény által (számszaki részekben és kiegészítő mellékletben) minimumként elöirt értéket.

A következőkben a Ragini által megalkotott tételcsoportokra vonatkozóan készített számításaink eredményeit közöljük. A csoportszintű számítások lehetőséget biztosítottak arra, hogy a gazdálkodók által az érdekhordozók számára átadott információk jellegét is megvizsgáljuk. Lehetővé vált továbbá annak az áttekintése is, hogy a magyar mintában hogyan változott az egyes témákkal kapcsolatos közzététel.

\subsection{Csoportszintü számítások}

A tételek csoportokra bontása további elemzéseket tesz lehetővé, amelyekből kiderül, hogy a magyar mintában szereplő gazdálkodók milyen típusú immateriális tételeket szerepeltetnek nagyobb súllyal a beszámolókban, illetve ezekben a tendenciákban milyen változás állt be az eltelt öt év alatt (2. ábra). A mintát alkotó cégek mindkét évben a szellemi tulajdonról, cégértékről, illetve a mérlegben szereplő immateriális tételeikről, valamint a környezeti és egyéb tényezőkről nyilatkoznak legtöbbet. 


\section{2. ábra}

\section{Kategóriánkénti átlagos tételszám a magyar beszámolókban}

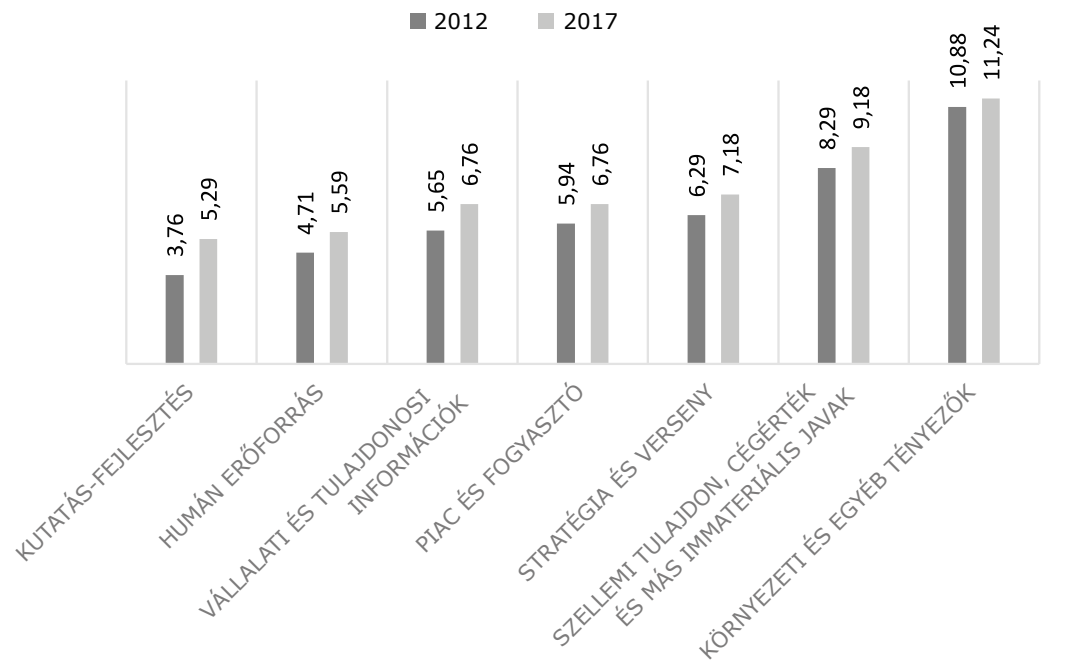

Forrás: saját szerkesztés

Ugyanakkor a piac és fogyasztó, a vállalati és tulajdonosi információk, illetve a stratégia és verseny csoportokból átlagosan 6-7 tétel úgy is bekerült a beszámolókba, hogy itt minimális a kötelezően előírt tételek száma. A humán erőforrás és kutatás-fejlesztés témakörökben voltak a legkevésbé közlékenyek a gazdálkodók - feltételezhetően utóbbinál jár a legtöbb kockázattal a kommunikáció.

A 2012-es értékek közel esnek az öt évvel későbbiekhez. A legnagyobb növekedés a vizsgált időszak alatt a kutatás-fejlesztés témánál jelentkezett. Olyan kategória nem volt, ahol csökkenés következett volna be, a legkisebb pozitív változás a környezeti információk esetében látszott - bár ez utóbbi eleve a legmagasabb átlagos értékkel bíró csoport. A többi, középmezőnybe tartozó halmaz esetében átlagosan közel eggyel nőtt a közölt tételek száma. Mindez azt jelenti, hogy az egyes kategóriák közötti eltérések csökkennek, vagyis idővel kiegyenlítettebb lett a közzététel tematikája.

Megvizsgáltuk a a beszámolóknak több mint a felében előforduló, viszonylag gyakori tételeket, illetve a szinte minden esetben mellékelt információkat (3. táblázat). A leggyakoribb tételeket megvizsgálva egyből szembetűnik a számviteli törvény hatása, szinte minden esetben a beszámoló számszaki részeiben vagy a szöveges mellékletben elöírt kötelező tartalmak jelennek meg. 
3. táblázat

A legyakrabban előforduló tételek

\begin{tabular}{|c|c|c|c|}
\hline $\begin{array}{l}\text { Ragini }(2012) \\
\text { csoportjai }\end{array}$ & $\begin{array}{c}\text { Legalább } \\
9 \text { beszámolóban szerepelt }\end{array}$ & \multicolumn{2}{|c|}{$\begin{array}{c}\text { Legalább } \\
16 \text { beszámolóban } \\
\text { szerepelt }\end{array}$} \\
\hline Kutatás-fejlesztés & Kutatás-fejlesztési költségek & \multicolumn{2}{|c|}{-} \\
\hline $\begin{array}{l}\text { Stratégia } \\
\text { és verseny }\end{array}$ & - & \multicolumn{2}{|c|}{-} \\
\hline \multirow{2}{*}{$\begin{array}{l}\text { Piac } \\
\text { és fogyasztó }\end{array}$} & Legfőbb termékek & \multicolumn{2}{|l|}{ Földrajzi eloszlás } \\
\hline & \multicolumn{3}{|l|}{$\begin{array}{l}\text { Marketing-/ } \\
\text { reklámköltségek }\end{array}$} \\
\hline \multirow{3}{*}{ Humán erőforrás } & \multirow{3}{*}{$\begin{array}{l}\text { Munkavállalók } \\
\text { létszáma szegmensenként }\end{array}$} & \multicolumn{2}{|c|}{ Munkavállalók létszáma } \\
\hline & & \multicolumn{2}{|c|}{$\begin{array}{l}\text { A vezetőség számára fizetett } \\
\text { javadalmazás és juttatások }\end{array}$} \\
\hline & & \multicolumn{2}{|c|}{ Információ az ügyvezetőkről } \\
\hline \multirow{7}{*}{$\begin{array}{l}\text { Szellemi tulajdon, } \\
\text { cégérték és más } \\
\text { immateriális javak }\end{array}$} & \multirow{7}{*}{$\begin{array}{l}\text { Cégérték és egyéb } \\
\text { immateriális javak } \\
\text { számviteli kezelése }\end{array}$} & \multicolumn{2}{|c|}{ Szellemi tulajdonjogok értéke } \\
\hline & & \multirow{2}{*}{$\begin{array}{l}\text { Egyéb immateriális } \\
\text { javak }\end{array}$} & értéke \\
\hline & & & tételei \\
\hline & & \multirow{4}{*}{$\begin{array}{l}\text { Cégérték és egyéb } \\
\text { immateriális javak }\end{array}$} & leírási módja \\
\hline & & & $\begin{array}{l}\text { hasznos } \\
\text { élettartama }\end{array}$ \\
\hline & & & $\begin{array}{l}\text { halmozott érték- } \\
\text { csökkenése }\end{array}$ \\
\hline & & & $\begin{array}{l}\text { könyv szerinti } \\
\text { értéke }\end{array}$ \\
\hline \multirow{3}{*}{$\begin{array}{l}\text { Vállalati } \\
\text { és tulajdonosi } \\
\text { információk }\end{array}$} & A vállalat története & \multicolumn{2}{|l|}{ Vállalati profil } \\
\hline & A részvényesek száma & \multicolumn{2}{|c|}{ A részvényesek eloszlása (típus szerint) } \\
\hline & $\begin{array}{l}\text { A részvényesek eloszlása } \\
\text { (birtokolt részvények száma } \\
\text { szerint) }\end{array}$ & \multicolumn{2}{|l|}{ Legföbb tulajdonosok } \\
\hline \multirow{6}{*}{$\begin{array}{l}\text { Környezeti } \\
\text { és egyéb tényezők }\end{array}$} & Környezeti kötelezettségek & \multicolumn{2}{|c|}{ Függő kötelezettségvállalások } \\
\hline & $\begin{array}{l}\text { Környezettel } \\
\text { kapcsolatos ügyek }\end{array}$ & \multirow{5}{*}{\multicolumn{2}{|c|}{ Tranzakciók kapcsolt felekkel }} \\
\hline & Környezeti költségek & & \\
\hline & $\begin{array}{l}\text { Környezethez kapcsolódó } \\
\text { termékek/technológiák }\end{array}$ & & \\
\hline & Mérlegen kívüli tételek & & \\
\hline & $\begin{array}{l}\text { Szerződéses } \\
\text { kötelezettségvállalások }\end{array}$ & & \\
\hline
\end{tabular}

Forrás: saját szerkesztés 
A kapott eredmények alapján arra következtethetünk, hogy a mintában szereplő magyar gazdálkodóknak az immateriális erőforrásokra vonatkozó beszámolási gyakorlatát jelenleg is erősen meghatározzák a számviteli törvényben lefektetett szabályok. A további vizsgálódásunk arra irányult, hogy azonosíthatók-e még olyan tényezők, amelyek bizonyíthatóan hatással vannak a közzétételre.

\subsection{Regressziós modell}

Munkánk során két időszakot (a 2012. és 2017. éveket) hasonlítottunk össze szimultán végzett regressziós modellek segítségével, logaritmizált adatokon. A rendelkezésre álló vállalatok száma korlátozza a minta nagyságát, ami miatt a hagyományos, legkisebb négyzetek módszere (OLS) helyett a kis minták elemzése során praktikusabb, robusztus regressziókat fogjuk alkalmazni. Ennek indoklásához előbb összefoglaljuk az OLS alkalmazása során fellépő statisztikai dilemmákat, majd bevezetjük a robusztus regressziókat - rámutatva arra, hogyan alkalmazhatók e dilemmák feloldására.

A regressziókkal szemben általánosságban a Gauss-Markov-feltételeket szokás megfogalmazni, amelyek a $\beta_{p}$ paraméterek linearitását az $N$ sokaságból vett minta véletlenszerüségét (a mintába tartozás kritériumai jól definiáltak és a változók függetlenek és azonos eloszlást követnek), a hibatag feltételesen nulla középértékét és homoszkedaszticitását takarják (Wooldridge, 2010). A legkisebb négyzetek módszere (OLS) szerint egy $p$ független változóból az alábbi lineáris regressziót (3) írhatjuk fel:

$y_{i}=\beta_{0}+\beta_{1} x_{i 1}+\cdots+\beta_{p} x_{i p}+\varepsilon_{i}, i=1,2, \ldots, n$,

ahol a modell illeszkedését a hibatagok mérete határozza meg, és a regreszsziós egyenestől messze eső pontokat kiugró értékeknek, azaz outliernek hívjuk. Módszertani szempontból azonban komoly kihívást jelent a $\varepsilon_{i}$ hibatag autokorrelálatlanságának és normális eloszlásának a biztosítása az alkalmazott tartalomelemzési módszer természetéből adódó kis mintanagyság miatt. Egy hagyományos OLS-regresszió esetében ez a koefficiensek torzítottságát és fals szignifikanciát okozná, amelyet a tőzsdei bevezetésre és az iparági besorolásra utaló vállalat-specifikus dummyváltozók valamelyest kompenzálhatnak. A logaritmizált adatok használatát hagyományosan robusztusnak szokás tekinteni az idősor átskálázása miatt, ha azonban az így létrejövő idősor nem vesz fel normális eloszlást, akkor a technika éppen, hogy növelni fogja változatosságot (Feng et al., 2014), azaz nem oldja meg a kiugró értékek problémáját. A gyakorlatban azonban sem ez, sem a ridge-regresszió nem biztosított autokorrelálatlan hibataggal rendelkező kimenetet, miközben a minta $\tau=0,5$ szerint vett kvantilis 
regressziója diagnosztikai szempontból nem bizonyult helyes döntésnek (sem a QSE-, sem a SQ-tesztek nem bizonyultak szignifikánsnak), vélhetően a kiugró értékek magas száma miatt.

A kis minták elemzése során népszerü, robusztus regressziók családja kínál megoldást a kiugró értékek okozta torzítások kezelésére - azzal, hogy a négyzetes hibatagok összegének, $\hat{\beta}=\min _{\mu \in R} \sum_{i=1}^{n}\left(y_{i}-\mu\right)^{2}$ minimalizálásának kritériumát cseréli le az outlierek által kevésbé befolyásolt eljárásra. Ilyen eljárás például az M-becslés, melynek során az outlierekre robusztus, a Kornacki-Bochniak (2015) által bevezetett maximum likelihood becsléséből indulunk ki (Susanti et al., 2014). Ebben a $\hat{\beta}=\beta_{n}\left(x_{1}, x_{2}, \ldots, x_{n}\right)$ koefficiensek becslése torzítatlan és minimális varianciájú, és a lépésenként újrasúlyozott legkisebb négyzetek (iteratively reweighted least squares - IRLS) módszerén (4) alapul:

$\sum_{i=1}^{n} x_{i j} w_{i}\left(y_{i}-\sum_{j=0}^{k} x_{i, j} \beta\right)=0, j=0,1, \ldots, k$.

A $w_{i}$ súlyfüggvény meghatározásához vezető utat a 2. melléklet tartalmazza. Az M-becslés alkalmazásával tehát a legkisebb négyzetes eltérések összegének hagyományos minimalizálása helyett az eltéréseknek egy $\rho$ függvényét minimalizáljuk ${ }^{4}$, amely a négyzetes függvénynél lassabb ütemben nő - ami az esetszámok csökkentése nélkül fogja csökkenteni a nagyobb eltéréseknek a becslésre gyakorolt súlyát (Csendes, 2015; Takács, 2012). A paraméterbecslések ismétlésével megkapjuk a $\hat{\beta}_{M}$ koefficiens konvergens értékeit. Az eljárás hátrányaként a hibatagok eloszlásával kapcsolatos feltételezések hiányát szokás kiemelni (Rousseeuw-Yohai, 1984). Azonban Yang et al. (2019) pontosan emiatt ajánlja vastag farkú és aszimmetrikus adatok elemzésére, miután a hely- és skálaparaméterek becslésére ma már többféle algoritmus is rendelkezésre áll (Csendes, 2015; Fegyverneki, 2003). A modellek illesztését Eviewsı1 szoftver segítségével végeztük el.

\subsection{Eredmények}

A 2012 és 2017-es évek közötti érdemi különbséget a nettó árbevétel jelentőségének pozitívvá válásán túl az immateriális javak jelentőségének nulla közelébe (sőt negatívvá váló) csökkenésénél tapasztalhatunk (4. táblázat), valamint 2017-re jelentőssé válnak az iparági különbségek a minta vállalatainak jelentéstételi gyakorlatában. Emellett, míg korábban az immateriális javak mérlegfőösszeg-arányos súlyának magasabb szintje kevésbé társult nagyobb beszámolási hajlandósággal,

$4 \hat{\beta}_{M}=\min _{\beta} \sum_{i=1}^{n} \rho\left(\frac{e_{i}}{\sigma}\right)=\min _{\beta} \sum_{i=1}^{n} \rho\left(\frac{y_{i}-\sum_{j=0}^{k} x_{i, j} \beta_{j}}{\sigma}\right)$ 
addig 2017-re ennek jelentősége is csökkenni látszik. Belátható, hogy a 2010-es évek második felére a stabilan legnagyobb árbevétellel rendelkező, hazai nagyvállalatok listáján szereplő cégek esetében a tőzsdei jegyzés mellett az árbevétel vált meghatározóvá a beszámolók információtartalmának minősége szempontjából, miközben a mérlegszerkezetnek csupán elenyésző szerep jutott.

\section{4. táblázat}

Robusztus legkisebb négyzetek módszerével (M-becsléssel) kapott eredmények

\begin{tabular}{|c|c|c|c|c|c|c|c|c|}
\hline Év & \multicolumn{4}{|c|}{2012} & \multicolumn{4}{|c|}{2017} \\
\hline változó & koeff. & st. hiba & z-stat. & $\mathrm{P}$ & koeff. & st. hiba & z-stat. & $\mathrm{P}$ \\
\hline konstans & 1,90 & 0,97 & 1,95 & 0,05 & 1,66 & 0,34 & 4,87 & 0,00 \\
\hline $\ln E K_{N A B}$ & $-0,21$ & 0,12 & $-1,77$ & 0,08 & 0,10 & 0,03 & 3,48 & 0,00 \\
\hline $\ln E_{I J}$ & 0,30 & 0,09 & 3,22 & 0,00 & $-0,04$ & 0,01 & $-6,75$ & 0,00 \\
\hline $\ln E_{\frac{I J}{M F O}}$ & $-0,28$ & 0,10 & $-2,85$ & 0,00 & $-0,02$ & 0,01 & $-3,53$ & 0,00 \\
\hline$d \_I_{t}$ & 0,82 & 0,18 & 4,51 & 0,00 & 1,65 & 0,04 & 39,55 & 0,00 \\
\hline$d \_I_{g}$ & 0,07 & 0,13 & 0,56 & 0,58 & 0,57 & 0,04 & 14,82 & 0,00 \\
\hline$d \_I_{e}$ & 0,02 & 0,13 & 0,14 & 0,89 & $-0,27$ & 0,04 & $-7,42$ & 0,00 \\
\hline \multicolumn{9}{|c|}{ robusztus statisztikák } \\
\hline R-négyzet & 0,50 & & & & 0,65 & & & \\
\hline Rw-négyzet & 0,97 & & & & 1,00 & & & \\
\hline Jarque-Bera & 4,97 & & & 0,08 & 12,16 & & & 0,002 \\
\hline Q-teszt & 0,991 & & & 0,318 & 0,3823 & & & 0,536 \\
\hline $\begin{array}{l}\text { homoszke- } \\
\text { daszticitás }\end{array}$ & 0,0187 & & & 0,891 & 0,1566 & & & 0,692 \\
\hline \multicolumn{9}{|c|}{ nem robusztus statisztikák } \\
\hline $\begin{array}{l}\text { függő változó } \\
\text { átlag }\end{array}$ & 3,10 & & & & 3,20 & & & \\
\hline $\begin{array}{l}\text { standard } \\
\text { hiba reg. }\end{array}$ & 0,35 & & & & 0,47 & & & \\
\hline
\end{tabular}

Forrás: saját szerkesztés, Eviewsı1 szoftver segítségével

Megjegyzés: súlyozás = bi-négyzet, skála = MAD (median centered), hat mátrix diagonálisával számolva a súlyozást

A hibatagok nem rendelkeztek autokorrelációval (Q-teszt) és heteroszkedaszticitással, így a koefficiensek becslése nem tekinthető torzítottnak.

A kapott eredmények részben összhangban vannak a szakirodalommal: a nettó árbevétel hatását Ragini (2012) is kimutatta Japán esetében. A tőzsdei jegyzés je- 
lentőségét korábbi kutatásunk során (Kovács, 2015) is kiemelkedőnek láttuk, viszont új elemként vizsgáltuk az iparágat. Az immateriális javak nettó értékéhez, illetve mérlegfőösszeghez viszonyított, relatív értékéhez kapcsolódó, előzetes várakozásaink nem teljesültek, szemben a Lippai-Makra et al. (2019) által publikált eredményekkel.

\section{4. ÖSSZEGZÉS}

Kutatásunk a tartalomelemzés módszerére építve tárta fel a legnagyobb árbevétellel rendelkező hazai vállalatok immateriális tételekkel kapcsolatos beszámolási kultúráját. A tételek listáját egy korábbi, nemzetközi mintán folytatott kutatásból vettük át, és a beszámolók tételes olvasásával rendeltünk pontértéket az egyes gazdálkodókhoz. Az eredmények azt mutatják, hogy a vizsgált két üzleti év között a pontértékek nagyon mérsékelt átlagos növekedést mutatnak, amely jelentősen kevesebb a szakirodalomban fellelt növekedési rátáknál. A közzétett adatok tematikáját tekintve elmondható, hogy a vizsgált gazdálkodók a szellemi tulajdonról, cégértékről, illetve a mérlegben szereplő immateriális tételeikről, valamint a környezeti és egyéb tényezőkről kommunikáltak legintenzívebben. A piac és fogyasztó, a vállalati és tulajdonosi információk, illetve a stratégia és verseny kategóriákba tartozó tételek utóbbiakhoz képest kisebb hangsúllyal szerepeltek. A humán erőforrás és kutatás-fejlesztés témakörökben voltak a legkevésbé közlékenyek a gazdálkodók. Következtetéseink között szerepel továbbá, hogy a mintában szereplő magyar gazdálkodók immateriális erőforrásokra vonatkozó beszámolási gyakorlatára az öt évvel későbbi adatok szerint is nagy hatással vannak a számviteli törvényben lefektetett szabályok.

Vizsgálatunk kiterjedt olyan tényezők azonosítására, amelyek bizonyíthatóan hatással voltak a mintában szereplő cégek közzétételi gyakorlatára. A tőzsdei jegyzés döntő szerepével kapcsolatban a korábbi kutatásaink eredményeit az újabb vizsgálat ismét megerősítette. Szintén e kutatási szakasz hozadéka a nettó árbevétel és az iparág mint a közzétételi gyakorlatot meghatározó tényezők azonosítása, azonban az immateriális javak nettó értékéhez, illetve a mérlegföösszeghez viszonyított, relatív értékéhez kapcsolódóan előzetes várakozásaink nem teljesültek.

A közzétételi intenzitást tekintve kiemelkedő pontszámot értek el azok a jellemzően tőzsdei gazdálkodók, amelyek az üzleti jelentést hozzáférhetővé tették, így e dokumentum online publikálása az immateriális javak szempontjából kulcsfontosságú - talán érdemes lenne a jelenlegi szabályozást e területen kiterjeszteni egyéb, nem nyilvánosan jegyzett nagyvállalatokra. Bizonyos vállalati méret (árbevétel) felett feltételezhetjük, hogy a gazdálkodók rendelkeznek olyan érdekhor- 
dozói körrel, amelynek szereplői hasznosítani tudnák az üzleti jelentésben szereplő információkat. A vezetőségi beszámolók ilyen módon történő közzététele tudatosabb jelentéskészítési magatartást eredményezhetne, valamint motiválhatná az önkéntes információközlést is.

Kutatásunk korlátai az alkalmazott módszerből erednek: Castilla-Polo-RuizRodríguez (2017) kiemeli a tartalomelemzési módszer két legnagyobb hátrányát. Az egyik az összehasonlíthatóság hiánya: még ha két kutató ugyanazt a tétellistát is követi, az információk és összefüggések emberi értelmezése miatt az eredmények nagyon korlátozottan hasonlíthatók össze. Elemzésünk további korlátja a vizsgált jelentések köre: az imént említett tanulmány alapján a hasonló vizsgálatok túlnyomó része szintén éves jelentések tartalmát elemzi. A jövőben elképzelhető a cégek által használt, egyéb kommunikációs formák bevonása is a kutatásokba, kiterjesztve a vizsgálatot például a fenntarthatósági jelentések, a vállalati honlapok, vagy akár a közösségi média segítségével közölt információkra is. A minta elemszámának növelése, illetve nemzetközi minta megalkotása segíthetné a munkánkat abban, hogy további statisztikai módszerek alkalmazásával feltárjunk országok közötti különbségeket. Mindenképpen érdemes lesz továbbá a tartalomelemzést kvalitatív módszerekkel kiegészíteni annak érdekében, hogy a közzététel mögött meghúzódó motivációs tényezőkről is ismereteket szerezzünk.

\section{MELLÉKLETEK}

\section{1. melléklet}

\section{A Ragini-féle tételek (2012)}

\begin{tabular}{ll}
\hline \multicolumn{2}{l}{ Tétel/Év } \\
\hline A. & Kutatás és fejlesztés \\
\hline a1 & K+F berendezések \\
\hline a2 & K+F tevékenység \\
\hline a3 & K+F személyzet \\
\hline a4 & K+F fókuszterületek \\
\hline a5 & K+F központok \\
\hline a6 & K+F struktúra \\
\hline a7 & K+F kezdeményezések \\
\hline a8 & K+F eredmények \\
\hline a9 & K+F költségek \\
\hline a10 & $\begin{array}{l}\text { K+F költségek az árbevételhez } \\
\text { viszonyítva }\end{array}$ \\
\hline a11 & K+F költségek növekedési rátája \\
\hline
\end{tabular}

\begin{tabular}{ll}
\hline \multicolumn{1}{c}{ Tétel/Év } \\
\hline a12 & $\begin{array}{l}\text { K+F költségek növekedésének } \\
\text { vagy csökkenésének oka }\end{array}$ \\
\hline a13 & $\begin{array}{l}\text { K+F költségek számviteli } \\
\text { kezelésmódja }\end{array}$ \\
\hline a14 & Folyamatban lévő K+F \\
\hline a15 & Technológia és innováció \\
\hline a16 & Technológiai know-how \\
\hline a17 & Új technológiák \\
\hline a18 & K+F finanszírozás részletei \\
\hline a19 & $\begin{array}{l}\text { Információtechnológiai } \\
\text { kezdeményezések }\end{array}$ \\
\hline a20 & Szoftverfejlesztési költségek \\
\hline & (A) Összesen \\
\hline
\end{tabular}




\begin{tabular}{|c|c|}
\hline & Tétel/Év \\
\hline \multirow[t]{2}{*}{ B. } & Stratégia és verseny \\
\hline & Stratégia: \\
\hline b1 & $\mathrm{K}+\mathrm{F}$ stratégia \\
\hline $\mathrm{b} 2$ & Humánerőforrás-stratégia \\
\hline b3 & $\begin{array}{l}\text { Szellemi tulajdonnal kapcsolatos } \\
\text { stratégia }\end{array}$ \\
\hline $\mathrm{b} 4$ & Termékstratégia \\
\hline b5 & Marketingstratégia \\
\hline b6 & Növekedési stratégia \\
\hline b7 & Növekedést vezérlő területek \\
\hline b8 & Üzleti stratégia \\
\hline b9 & Szállítókkal kapcsolatos stratégia \\
\hline $\mathrm{b} 10$ & Befektetési stratégia \\
\hline b11 & Globális stratégia \\
\hline b12 & Regionális stratégia \\
\hline b13 & Vezetési stratégia \\
\hline b14 & Erősségek \\
\hline b15 & Kockázatmenedzsment \\
\hline b16 & Likviditásmenedzsment \\
\hline b17 & Stratégiai kérdések \\
\hline b18 & Stratégiai célok \\
\hline b19 & Stratégiai kezdeményezések \\
\hline b20 & Átszervezési tevékenység \\
\hline b21 & Stratégiai szövetségek \\
\hline b22 & $\begin{array}{l}\text { Költségkövetési intézkedések/ } \\
\text { kezdeményezések }\end{array}$ \\
\hline $\mathrm{b} 23$ & Finanszírozási stratégia \\
\hline \multirow[t]{2}{*}{ b24 } & Ellátásilánc-menedzsment \\
\hline & Verseny: \\
\hline b25 & A verseny minősége, erőssége \\
\hline $\mathrm{b} 26$ & Kompetitív faktorok \\
\hline b27 & Kulcsversenytársak \\
\hline b28 & Ipari trendek/környezet \\
\hline b29 & Kockázati faktorok \\
\hline b30 & $\begin{array}{l}\text { A globális versenyben való } \\
\text { helytállás érdekében tett } \\
\text { erőfeszítések }\end{array}$ \\
\hline
\end{tabular}

\begin{tabular}{|c|c|}
\hline & Tétel/Év \\
\hline \multirow[t]{2}{*}{ C. } & Piac és fogyasztó \\
\hline & Piac: \\
\hline $\mathrm{cl}$ & Elsődleges piacok \\
\hline $\mathrm{c} 2$ & Legfőbb termékek \\
\hline c3 & Új termékek \\
\hline $\mathrm{c} 4$ & $\begin{array}{l}\text { Az új termékek aránya az összes } \\
\text { termékhez viszonyítva }\end{array}$ \\
\hline c5 & Piaci egységek/üzletek \\
\hline c6 & Az új egységek/üzletek száma \\
\hline c7 & Új piacok/célpiacok \\
\hline c8 & Piaci kockázat \\
\hline c9 & Piaci részesedés \\
\hline $\mathrm{c10}$ & Marketing/reklám költségek \\
\hline $\mathrm{c} 11$ & Piaci növekedés \\
\hline $\mathrm{c} 12$ & Márkanevek \\
\hline $\mathrm{c} 13$ & Legfőbb márkák \\
\hline $\mathrm{c} 14$ & Elosztási rendszer \\
\hline $\mathrm{c} 15$ & Kereskedők száma \\
\hline $\mathrm{c} 16$ & Legfőbb szállítók \\
\hline c17 & Szállítói kapcsolatok \\
\hline $\mathrm{c} 18$ & $\begin{array}{l}\text { Az árbevétel aránya az iparági } \\
\text { értékesítéshez viszonyítva }\end{array}$ \\
\hline $\mathrm{c} 19$ & Vezető a piacon \\
\hline $\mathrm{c} 20$ & Márkák száma \\
\hline $\mathrm{c} 21$ & A márka értéke \\
\hline $\mathrm{c} 22$ & Márkaépítés \\
\hline $\mathrm{c} 23$ & Promóció/Marketingtevékenység \\
\hline c24 & $\begin{array}{l}\text { A termék egy före jutó } \\
\text { fogyasztása }\end{array}$ \\
\hline $\mathrm{c} 25$ & Termékminőség \\
\hline \multirow[t]{2}{*}{$\mathrm{c} 26$} & Termékdizájn \\
\hline & Fogyasztó: \\
\hline $\mathrm{c} 27$ & Vásárlóbázis \\
\hline c28 & Legfőbb vásárlók \\
\hline c29 & Új vásárlók \\
\hline c30 & Vevőhűség \\
\hline $\mathrm{c} 31$ & Vevőkapcsolatok \\
\hline
\end{tabular}




\begin{tabular}{|c|c|}
\hline & Tétel/Év \\
\hline c32 & Vevőlista \\
\hline c33 & Földrajzi eloszlás \\
\hline c34 & Értékesítésösztönzés \\
\hline c35 & Vevői elégedettség \\
\hline \multirow[t]{2}{*}{ c36 } & Vevőszolgálat \\
\hline & (C.) Összesen \\
\hline D. & Humán erőforrás \\
\hline d1 & Munkavállalók száma \\
\hline $\mathrm{d} 2$ & $\begin{array}{l}\text { Munkavállalók száma } \\
\text { szegmensenként }\end{array}$ \\
\hline d3 & $\begin{array}{l}\text { Munkavállalók száma } \\
\text { területenként }\end{array}$ \\
\hline $\mathrm{d} 4$ & Új munkavállalók \\
\hline $\mathrm{d} 5$ & Munkavállalók korösszetétele \\
\hline d6 & Munkavállalók átlagos életkora \\
\hline d7 & $\begin{array}{l}\text { Munkavállalók nemek szerinti } \\
\text { összetétele }\end{array}$ \\
\hline $\mathrm{d} 8$ & Munkavállalók képzettsége \\
\hline d9 & A humán erőforrás értéke \\
\hline $\mathrm{d} 10$ & $\begin{array}{l}\text { A humán erőforrás egy } \\
\text { munkavállalóra eső értéke }\end{array}$ \\
\hline d11 & $\begin{array}{l}\text { A humán erőforrással kapcsolatos } \\
\text { megtérülés }\end{array}$ \\
\hline d12 & Képzési programok \\
\hline d13 & $\begin{array}{l}\text { Humánerőforrás-fejlesztési } \\
\text { tevékenység }\end{array}$ \\
\hline $\mathrm{d} 14$ & Vezetőség \\
\hline d15 & $\begin{array}{l}\text { Toborzási és munkaerőfelvételi } \\
\text { programok }\end{array}$ \\
\hline d16 & Munkavállalói kapcsolatok \\
\hline d17 & Ipari kapcsolatok \\
\hline $\mathrm{d} 18$ & Javadalmazási politika \\
\hline d19 & $\begin{array}{l}\text { A vezetőség számára fizetett } \\
\text { javadalmazás és juttatások }\end{array}$ \\
\hline $\mathrm{d} 20$ & Munkavállalói ösztönzési terv \\
\hline $\mathrm{d} 21$ & Nyugdíjjal kapcsolatos juttatások \\
\hline $\mathrm{d} 22$ & $\begin{array}{l}\text { Munkatermelékenység alakulása } \\
\text { (több évre) }\end{array}$ \\
\hline
\end{tabular}

\begin{tabular}{|c|c|}
\hline & Tétel/Év \\
\hline $\mathrm{d} 23$ & $\begin{array}{l}\text { Képzésben részt vett } \\
\text { munkavállalók száma }\end{array}$ \\
\hline $\mathrm{d} 24$ & Munkavállalói elégedettség \\
\hline $\mathrm{d} 25$ & Információ az ügyvezetőkről \\
\hline \multirow[t]{2}{*}{$\mathrm{d} 26$} & $\begin{array}{l}\text { Egy munkavállalóra jutó } \\
\text { árbevétel }\end{array}$ \\
\hline & (D) Összesen \\
\hline \multirow[t]{2}{*}{ E. } & $\begin{array}{l}\text { Szellemi tulajdonjogok, cégérték } \\
\text { és egyéb immateriális javak }\end{array}$ \\
\hline & Szellemi tulajdonjogok: \\
\hline e1 & Szellemi tulajdonjogok értéke \\
\hline $\mathrm{e} 2$ & Szabadalmak száma \\
\hline e3 & Szabadalmak száma területenként \\
\hline $\mathrm{e} 4$ & Szabadalmak értéke \\
\hline e5 & Megszerzett szabadalmak értéke \\
\hline e6 & Szabadalmak rangja \\
\hline e7 & $\begin{array}{l}\text { Kereskedelmi márkák/nevek } \\
\text { értéke }\end{array}$ \\
\hline e8 & Bejegyzett márkák neve \\
\hline e9 & Szellemi tulajdon körforgása \\
\hline $\mathrm{e} 10$ & $\begin{array}{l}\text { Szellemi tulajdonnal kapcsolatos } \\
\text { tevékenységek }\end{array}$ \\
\hline e11 & Szellemi tulajdon menedzsmentje \\
\hline e12 & $\begin{array}{l}\text { Üzleti titkokról, szerzői jogokról } \\
\text { szóló információ }\end{array}$ \\
\hline \multirow[t]{2}{*}{ e13 } & Vevőkapcsolatok értéke \\
\hline & $\begin{array}{l}\text { Cégérték és más immateriális } \\
\text { javak: }\end{array}$ \\
\hline e14 & Cégérték értéke \\
\hline e15 & Szerzett cégérték értéke \\
\hline e16 & Cégérték szegmensenkénti értéke \\
\hline e17 & Cégérték területenkénti értéke \\
\hline e18 & Egyéb immateriális javak értéke \\
\hline e19 & Egyéb immateriális javak tételei \\
\hline $\mathrm{e} 20$ & $\begin{array}{l}\text { Cégérték és egyéb immateriális } \\
\text { javak számviteli kezelése }\end{array}$ \\
\hline $\mathrm{e} 21$ & $\begin{array}{l}\text { Cégérték és egyéb immateriális } \\
\text { javak leírási módja }\end{array}$ \\
\hline
\end{tabular}




\begin{tabular}{ll}
\hline & Tétel/Év \\
\hline e22 & $\begin{array}{l}\text { Cégérték és egyéb immateriális } \\
\text { javak hasznos élettartama }\end{array}$ \\
\hline e23 & $\begin{array}{l}\text { Cégérték és egyéb immateriális } \\
\text { javak halmozott értékcsökkenése }\end{array}$ \\
\hline e24 & $\begin{array}{l}\text { Cégérték és egyéb immateriális } \\
\text { javak könyv szerinti értéke }\end{array}$ \\
\hline e25 & $\begin{array}{l}\text { Cégérték és egyéb immateriális } \\
\text { kritériumai }\end{array}$ \\
\hline & (E) Összesen \\
\hline F. & Vállalati és tulajdonosi tesztjének \\
információk
\end{tabular}

\begin{tabular}{|c|c|}
\hline & Tétel/Év \\
\hline \multirow[t]{2}{*}{ G. } & Környezeti és egyéb \\
\hline & Környezet: \\
\hline g1 & Környezeti tevékenységek \\
\hline g2 & Környezeti filozófia \\
\hline g3 & $\begin{array}{l}\text { Környezettel kapcsolatos } \\
\text { programok/politikák }\end{array}$ \\
\hline g4 & Környezeti kezdeményezések \\
\hline g5 & Környezeti kötelezettségek \\
\hline g6 & Környezetmenedzsment-elvek \\
\hline g7 & Környezettel kapcsolatos ügyek \\
\hline g8 & Környezeti költségek \\
\hline \multirow[t]{2}{*}{ g9 } & $\begin{array}{l}\text { Környezethez kapcsolódó } \\
\text { termékek/technológiák }\end{array}$ \\
\hline & Egyéb: \\
\hline g10 & $\begin{array}{l}\text { A vállalat társadalmi } \\
\text { felelősségvállalása }\end{array}$ \\
\hline g11 & Vállalatirányítás \\
\hline g12 & Tartalékok, elkötelezettségek \\
\hline g13 & Mérlegen kívüli megállapodások \\
\hline g14 & Lízingek \\
\hline g15 & $\begin{array}{l}\text { Kapcsolt vállalkozásokkal } \\
\text { folytatott tranzakciók }\end{array}$ \\
\hline g16 & Fedezeti ügyletek \\
\hline g17 & $\begin{array}{l}\text { Pénzügyi instrumentumok } \\
\text { valós értéke }\end{array}$ \\
\hline g18 & Szerződéses kötelezettségek \\
\hline g19 & Új számviteli standardok \\
\hline g20 & Számvitelpolitikai változások \\
\hline g21 & Jövőkép \\
\hline g22 & $\begin{array}{l}\text { Mérlegfordulónap utáni } \\
\text { események }\end{array}$ \\
\hline g23 & Lehetőségek és kihívások \\
\hline g24 & Elnyert díjak \\
\hline g25 & Adósminősítési besorolás \\
\hline & (G) Összesen \\
\hline
\end{tabular}




\section{2. melléklet}

Az M-becslésnél a hibatag $\rho$ függvényének a minimalizálása a cél: $\hat{\beta}_{M}=\min _{\beta} \sum_{i=1}^{n} \rho\left(\frac{e_{i}}{\sigma}\right)=\min _{\beta} \sum_{i=1}^{n} \rho\left(\frac{y_{i}-\sum_{j=0}^{k} x_{i, j} \beta_{j}}{\sigma}\right)$, miközben a $\hat{\sigma}$ skálaparamétert a $\hat{\sigma}=\frac{\text { medián } \mid e_{i}-\text { median }\left(e_{i}\right) \mid}{0,6745}$ összefüggés mentén becsülhetjük. A $\hat{\beta}_{M}$ első parciális deriváltjának súlyfüggvényével $\left(w\left(e_{i}\right)=\frac{\frac{y_{i}-\sum_{j=0}^{k} x_{i, j} \beta}{\hat{\partial}}}{\frac{y_{i}-\sum_{j=0}^{k} x_{i, j} \beta}{\widehat{o}}}\right)$ a Tukey-bi-négyzet célfüggvényét $\left(w_{i}=\left\{\begin{array}{c}\left.\left[1-\left(\frac{u_{i}}{c}\right)^{2}\right]^{2}, h a\left|u_{i}\right| \leq 4,685\right) \text { összekapcsolva kapjuk meg a súlyfügg- } \\ 0, h a\left|u_{i}\right|>4,685\end{array}\right.\right.$ vényt.

\section{HIVATKOZÁSOK}

Albu, N. - Albu, C. N. - Filip, A. (2017): Corporate Reporting in Central and Eastern Europe: Issues, Challenges and Research Opportunities. Accounting in Europe 14, 249-26o. https://doi. org/10.1080/17449480.2017.1385819.

Bellora, L. - Guenther, T. W. (2013): Drivers of innovation capital disclosure in intellectual capital statements: Evidence from Europe. The British Accounting Review 45, 255-270. https:// doi.org/10.1016/j.bar.2013.06.002.

BodA György - Révész TAMÁs - Losonci Dávid - FÜlöp Zoltán (2019): A növekedési ütem és a foglalkoztatás növelésének lehetőségeiről. Közgazdasági Szemle 66, 376-417. https://doi. org/10.18414/KSZ.2019.4.376.

Bogdan, V. - Platon, J. - Popa, D. N. (2011): Intellectual capital reporting and disclosure in the annual reports of romanian manufacturing listed companies - Methodology and discussion of results. Annals of Faculty of Economics 1, 466-476. http://anale.steconomiceuoradea.ro/ volume/2011/n2/065.pdf.

Boujelbene, M. A. - Affes, H. (2013): The impact of intellectual capital disclosure on cost of equity capital: A case of French firms. Journal of Economics Finance and Administrative Science 18, 45-53. https://doi.org/10.1016/S2077-1886(13)70022-2.

Brand Finance (2018): Global Intangible Finance Tracker (GIFT).

Castilla-Polo, F. - Ruiz-Rodríguez, C. (2017): Content analysis within intangible assets disclosure: a structured literature review. Journal of Intellectual Capital 18, 506-543. https://doi. org/10.1108/JIC-11-2016-0123.

Csendes Csilla (2014): Szimmetrikus stabil eloszlások paramétereinek egy robusztus becslési eljárása és alkalmazása. PhD-értekezés, Hatvany József Informatikai Tudományok Doktori Iskola, Miskolci Egyetem. http://midra.uni-miskolc.hu:8o/?docId=19054. 
FEgYVERNEKI SÁNDOR (2003): Robust estimators and probability integral transformations. Mathematical and Computer Modelling, Hungarian Applied Mathematics 38(7-9), 803-814. https://doi.org/10.1016/So895-7177(03)90065-3.

Feng, C. - WAng, H. - Lu, N. - Chen, T. - He, H. - Lu, Y. - Tu, X. M. (2014): Log-transformation and its implications for data analysis. Shanghai Arch Psychiatry 26, 105-109. https://doi.org/10.3969/j. issn.1002-0829.2014.02.009.

Figyelő (2018): Figyelő Top 200: Magyarországi legnagyobb cégei 2018.

Figyelő (2013): Figyelő Top 200: Magyarországi cégek ranglistái.

Gambetti, R. C. - Melewar, T. C. - Martin, K. D. (2017): Guest Editors' Introduction: Ethical Management of Intangible Assets in Contemporary Organizations. Business Ethics Quarterly 27, 381-392, https://doi.org/10.1017/beq.2017.21.

Ho, H. - Chau, K. - Cheung, P. (2012): Intellectual Capital Disclosure and Initial Public Offerings: Evidence from Hong Kong. Journal of Applied Economics and Business Research 2(2), 56-68. https://pdfs.semanticscholar.org/d6e7/ed 47763fa5c8ffo 253 d54ccf843baefoo 738 .pdf.

JuHÁsz PÉTER (2016): Management under Limited Information - The Measurement of Off-Balance Sheet Assets at Hungarian firms. Central European Business Review 5, 23-33. https://doi. org/10.18267/j.cebr.164.

Kornacki, A. - Bochniak, A. (2015): The use of outlier detection methods in the log-normal distribution for the identification of atypical varietal experiments. Biometrical Letters 52, 75-84. https://doi.org/10.1515/bile-2015-0007.

KovÁcs Zsuzsanna ILONA (2015): Immateriális vagyonelemek a magyar számviteli rendszerben és a beszámolókban. Pénzügyi Szemle 6o, 231-242. https://www.penzugyiszemle.hu/documents/ kovacszs-2015-2-mpdf_20170817154649_91.pdf.

KPMG International (2020): The Time Has Come: The KPMG Survey of Sustainability Reporting 2020. https://home.kpmg/xx/en/home/insights/2020/11/the-time-has-come-survey-ofsustainability-reporting.html.

LAÁв ÁGNes (2010): Kompetencia-ga(rá)zdálkodás I. Budapesti Müszaki és Gazdaságtudományi Egyetem, Budapest: Typotex Kiadó.

LEv, B. (2003): Remarks on the Measurement, Valuation, and Reporting of Intangible Assets. Economic Policy Review 9(3), 17-22. https://papers.ssrn.com/sol3/papers.cfm?abstract_id=1280689.

Li, J. - Pike, R. - Haniffa, R. (2008): Intellectual capital disclosure and corporate governance structure in UK firms. Accounting and Business Research 38, 137-159. https://doi.org/10.108o/o 0014788.2008.9663326.

Lippai-Makra Edit - RÁdóczi Zsolt - Kovács Zsuzsanna Ilona (2019): Intellectual capital disclosure of Hungarian and Czech Listed firms. European Financial and Accounting Journal 14, 43-59. https://doi.org/10.18267/j.efaj.229.

NovÁk, M. (2018): The Quality of Disclosure under IAS 38 in Financial Statements of Entities Listed on PSE. European Financial and Accounting Journal 2018, 31-44. https://doi.org/10.18267/j. efaj.208.

OECD (2012): Corporate Reporting of Intangible Assets: A Progress Report. https://www.oecd.org/ daf/ca/Intangible\%2oAssets.pdf.

Oliveira, L. - Rodrigues, L.- Craig, R. (2006): Firm-specific determinants of intangibles reporting: evidence from the Portuguese stock market. Journal of Human Resource Costing \& Accounting 10, 11-33. https://doi.org/10.1108/14013380610672657.

OrhangazI, Ö. (2019): The role of intangible assets in explaining the investment-profit puzzle. Cambridge Journal of Economics 43, 1251-1286. https://doi.org/10.1093/cje/beyo46. 
Petty, R. - Cuganesan, S. - Finch, N. - Ford, G. (2009): Intellectual Capital and Valuation: Challenges in the Voluntary Disclosure of Value Drivers. SSRN Electronic Journal. https://doi. org/10.2139/ssrn.1490208

Ragini, J. R. (2012): Corporate Disclosure of Intangibles: A Comparative Study of Practices among Indian, US, and Japanese Companies. Vikalpa 37,51-72.https://doi.org/10.1177/0256090920120305.

Rousseeuw, P. - Yohai, V. (1984): Robust Regression by Means of S-Estimators, in: Franke, J., Härdle, W., Martin, D. (Eds.), Robust and Nonlinear Time Series Analysis, Lecture Notes in Statistics. New York: Springer US, 256-272. https://doi.org/10.1007/978-1-4615-7821-5_15.

SAXné ANDOR ÁGnes MÁRTA (2014): Az immateriális javak számviteli elmélete és alkalmazása a magyar szabályozási rendszerben. PhD-értekezés. http://phd.lib.uni-corvinus.hu/774/.

Shemata, N. F. (2014): Theories and Determinants of Voluntary Disclosure. Accounting and Finance Research 3. https://doi.org/10.5430/afr.v3n1p18.

Susanti, Y. - Pratiwi, H. - Sulistijowati H. S. - Liana, T. (2014): M estimation, S estimation, and MM estimation in robust regression. International Journal of Pure and Apllied Mathematics 91, 349-36o. https://doi.org/10.12732/ijpam.v91i3.7.

SveIBY, K.E. (2001): Szervezetek új gazdagsága: a menedzselt tudás. Budapest: KJK-KERSZÖV.

TAKÁCs SzABOLCS (2012): Érzékenységvizsgálatok a statisztikai eljárásokban. Alkalmazott Matematikai Lapok 29, 67-10o. http://aml.math.bme.hu/wp-content/uploads/2012/o6/29-Tak\%C3\%A1cs. pdf.

Wooldridge, J. M. (2010): Econometric Analysis of Cross Section and Panel Data, Second Edition.| Cambridge: The MIT Press.

YAng, T. - Gallagher, C. M. - McMahan, C. S. (2019): A robust regression methodology via M-estimation. Communications in Statistics - Theory and Methods 48, 1092-1107. https://doi.or g/10.1080/03610926.2018.1423698.

Zambon, S. - Marzo, G. -Girella, L. -Abela, M. - D’Albore, N. (2020): A literature review on the reporting of intangibles. Academic Report. https:/www.efrag.org/Assets/Download?assetU $\mathrm{rl}=\% 2$ Fsites\%2Fwebpublishing\%2FSiteAssets\%2FA\%252oliterature\%252oreview\%2520on\%2520t he\%2520reporting\%25200f\%2520intangibles.pdf. 